\title{
Metal-Free Hybrid Organic-Inorganic Perovskites for Photovoltaics
}

\author{
Tianmin $\mathrm{Wu}^{1,3 \dagger}$, Xian Chen ${ }^{2, \dagger}$, Jian Wang ${ }^{1, *}$ \\ 1 College of Physics and Optoelectronic Engineering, Shenzhen University,
} Shenzhen 518060, China

2 College of Artificial Intelligence, Yango University, Fuzhou 350015, China

3 Department of Physics and HKU-UCAS Joint Institute for Theoretical and Computational Physics at Hong Kong, The University of Hong Kong, Hong Kong, China

* To whom correspondence should be addressed. E-mail: jianwang@hku.hk

$\dagger$ These authors contribute equally to this work. 


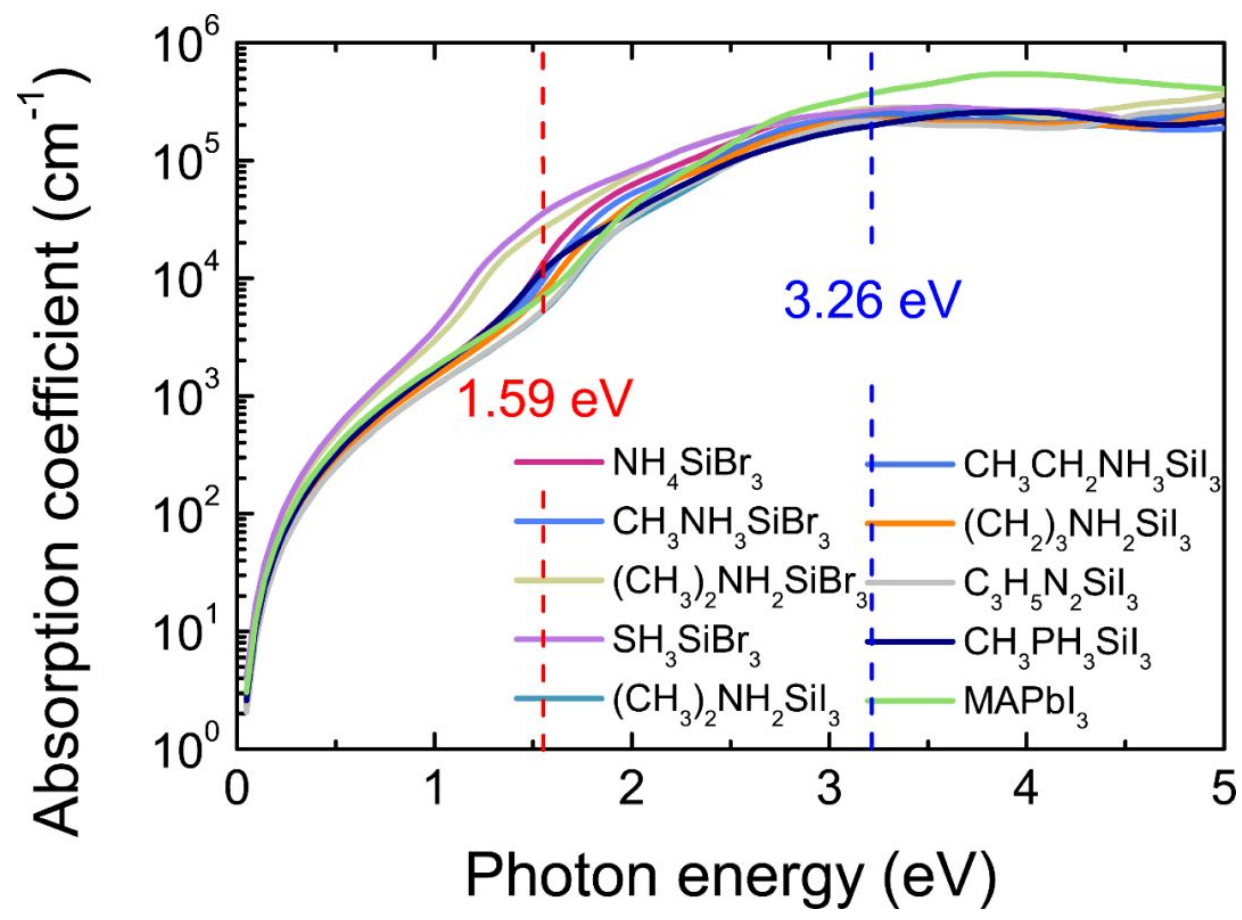

Figure S1. Computational optical absorption spectra of 9 Silicon-based HOIPs, including $\mathrm{NH}_{4} \mathrm{SiBr}_{3}, \quad \mathrm{CH}_{3} \mathrm{CH}_{2} \mathrm{NH}_{3} \mathrm{SiBr}_{3}, \quad \mathrm{CH}_{3} \mathrm{NH}_{3} \mathrm{SiBr}_{3}$, $\left(\mathrm{CH}_{2}\right)_{3} \mathrm{NH}_{2} \mathrm{SiBr}_{3}, \quad\left(\mathrm{CH}_{3}\right)_{2} \mathrm{NH}_{2} \mathrm{SiI}_{3}, \quad \mathrm{C}_{3} \mathrm{H}_{5} \mathrm{H}_{2} \mathrm{SiI}_{3}, \quad \mathrm{SH}_{3} \mathrm{SiBr}_{3}, \quad \mathrm{CH}_{3} \mathrm{PH}_{3} \mathrm{SiI}_{3}$, $\left(\mathrm{CH}_{2}\right)_{3} \mathrm{NH}_{2} \mathrm{SiI}_{3}$, compared with the optical absorption spectra of the representative $\mathrm{MAPbI}_{3}$. 
(a)
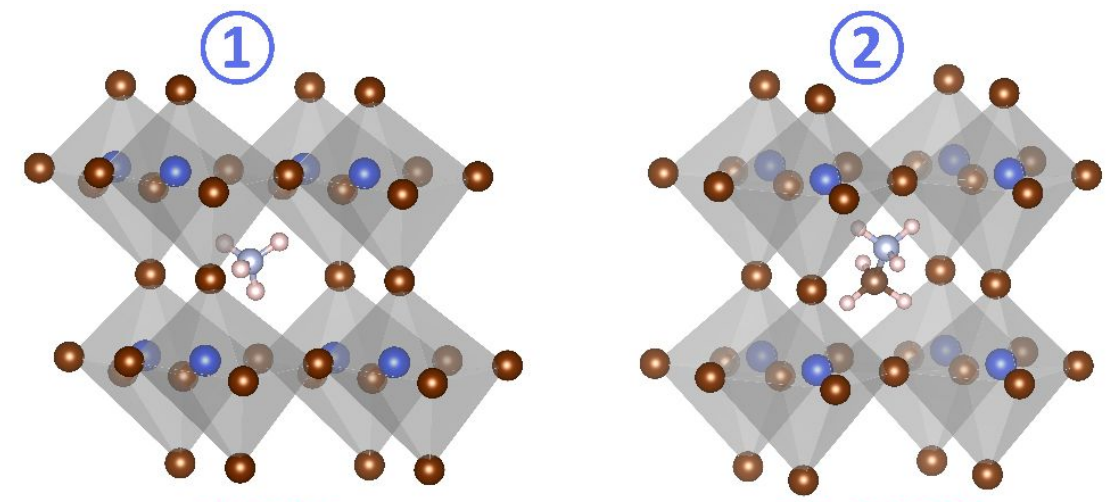

$\mathrm{NH}_{4} \mathrm{SiBr}$

$\mathrm{CH}_{3} \mathrm{NH}_{3} \mathrm{SiBr}_{3}$

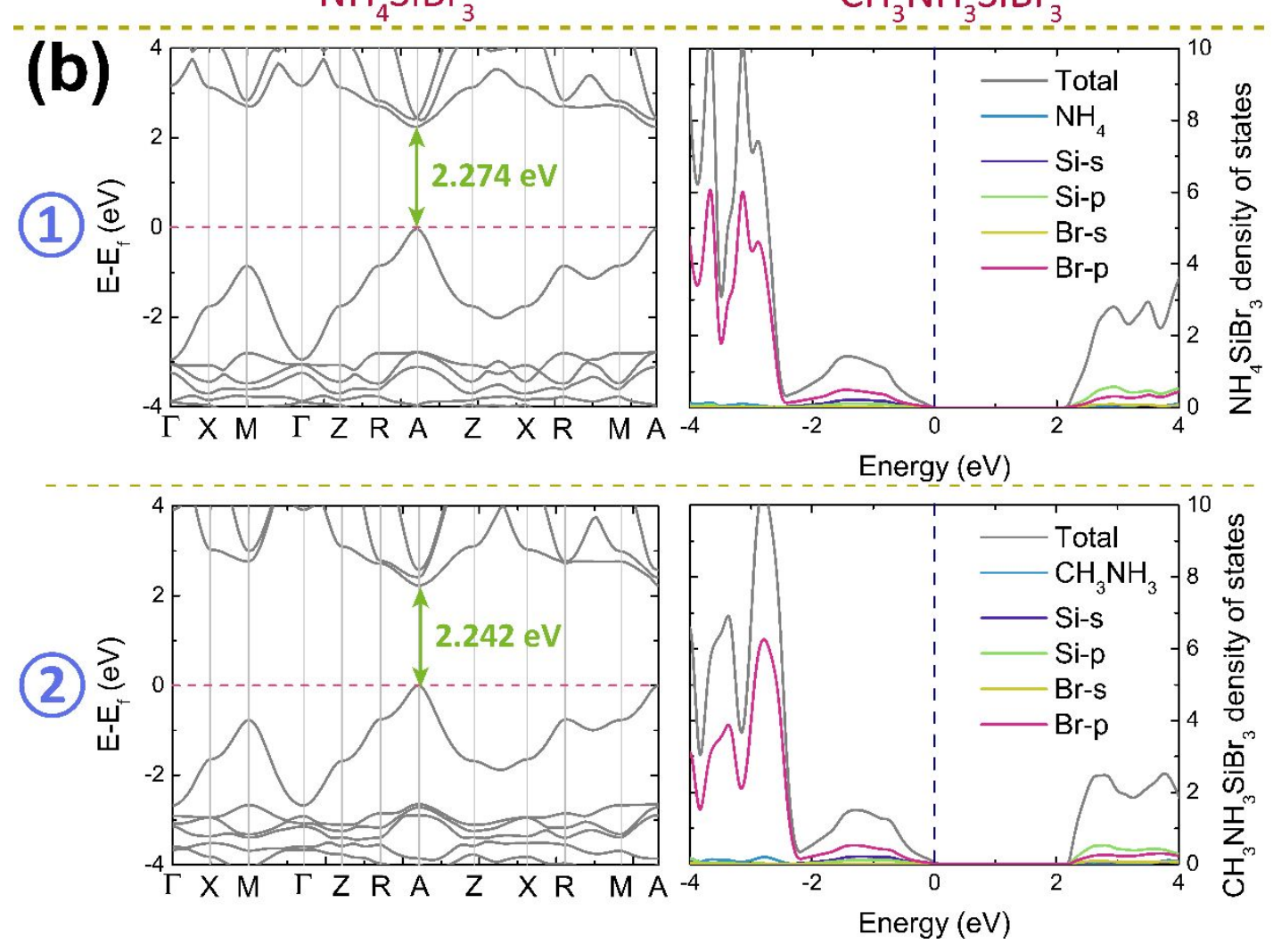

Figure S2. (a) The optimized structures, (b) band structures and PDOS for $\mathrm{NH}_{4} \mathrm{SiBr}_{3}$ and $\mathrm{CH}_{3} \mathrm{NH}_{3} \mathrm{SiBr}_{3}$. 
(a)
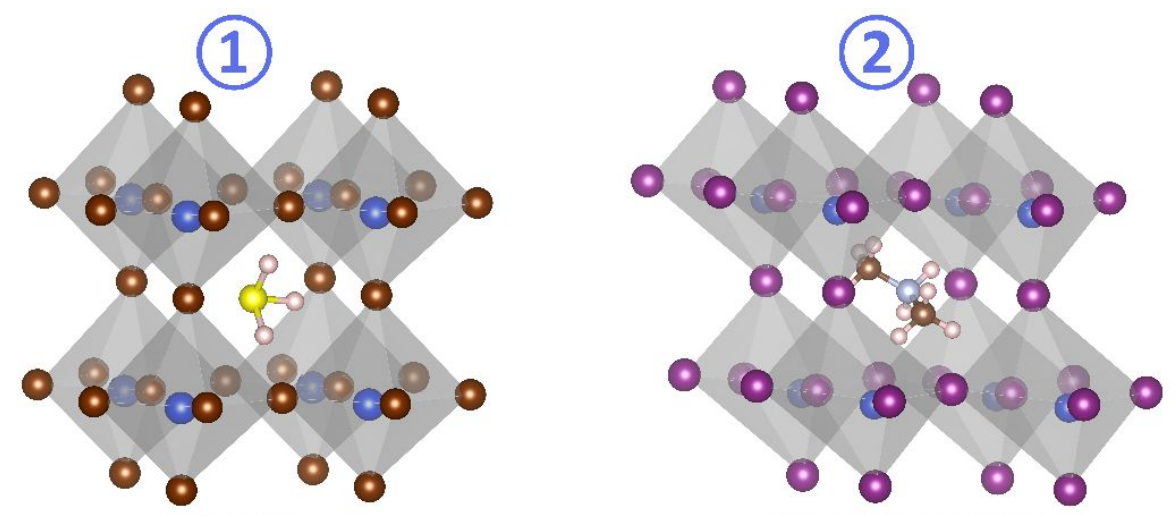

$\mathrm{SH}_{3} \mathrm{SiBr}_{3}$

$\left(\mathrm{CH}_{3}\right)_{2} \mathrm{NH}_{2} \mathrm{Sil}_{3}$

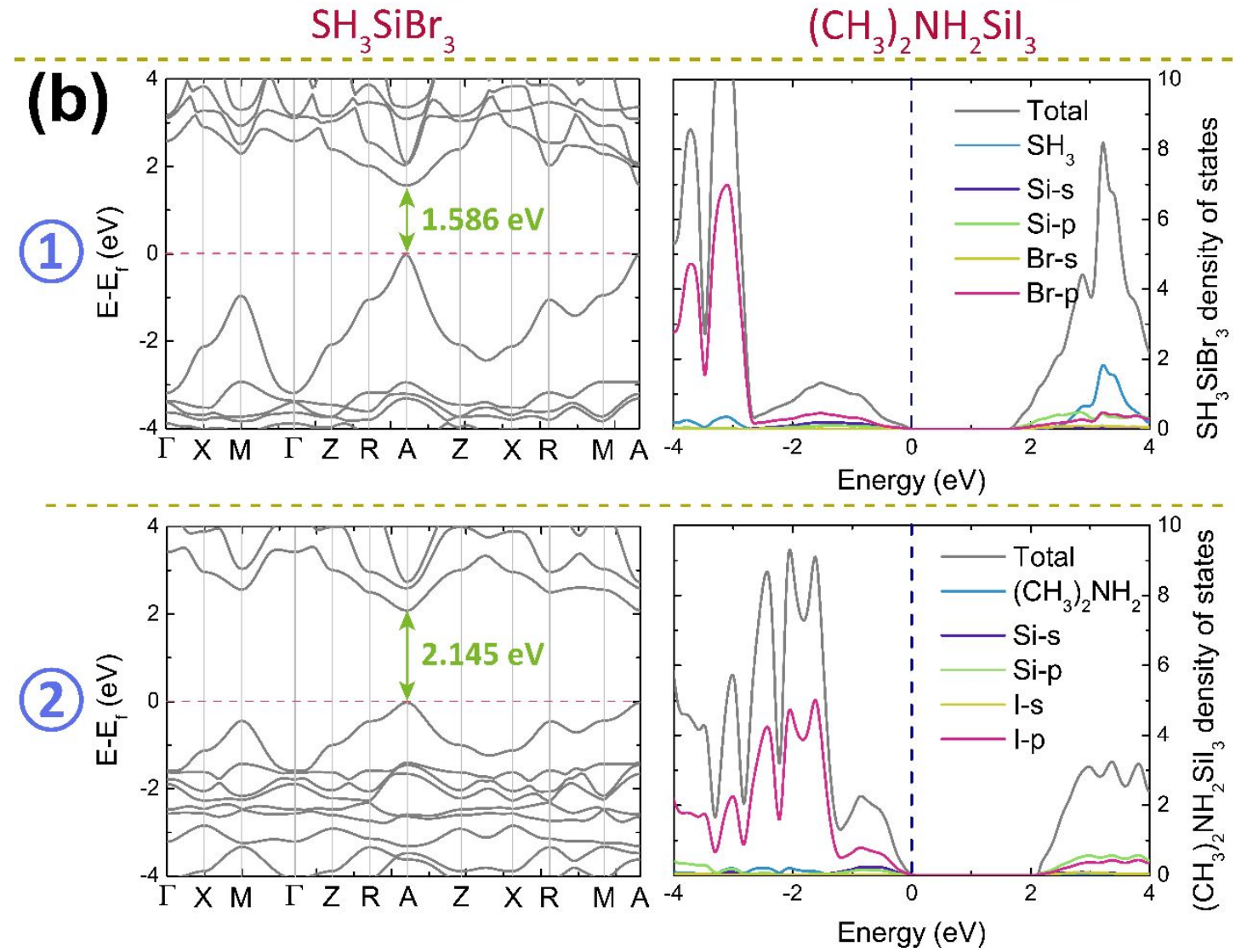

Figure S3. (a) The optimized structures, (b) band structures and PDOS for $\mathrm{SH}_{3} \mathrm{SiBr}_{3}$ and $\left(\mathrm{CH}_{3}\right)_{2} \mathrm{NH}_{2} \mathrm{SiI}_{3}$. 
(a)
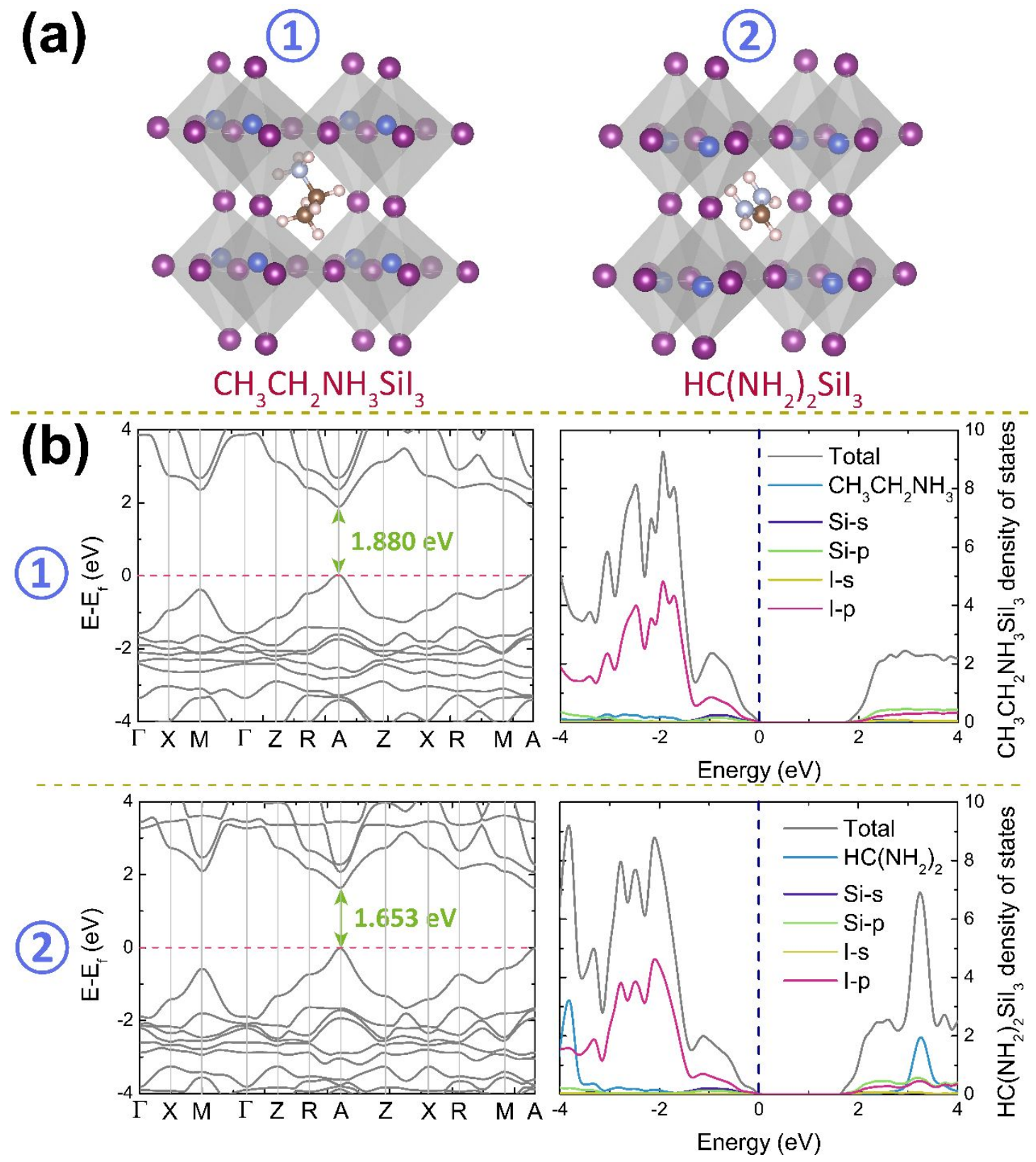

Figure S4. (a) The optimized structures, (b) band structures and PDOS for $\mathrm{CH}_{3} \mathrm{CH}_{2} \mathrm{NH}_{3} \mathrm{SiI}_{3}$ and $\mathrm{HC}\left(\mathrm{NH}_{2}\right)_{2} \mathrm{SiI}_{3}$. 
(a)

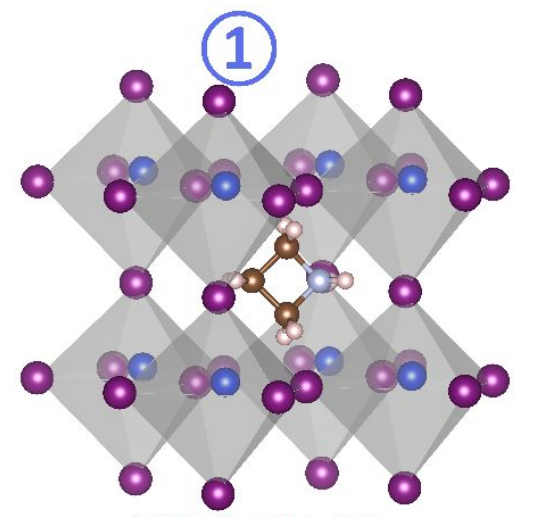

$\left(\mathrm{CH}_{2}\right)_{3} \mathrm{NH}_{2} \mathrm{Sil}_{3}$

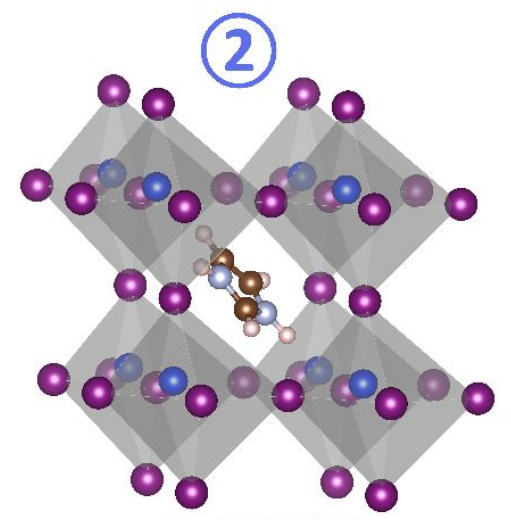

$\mathrm{C}_{3} \mathrm{H}_{5} \mathrm{~N}_{2} \mathrm{Sil}_{3}$

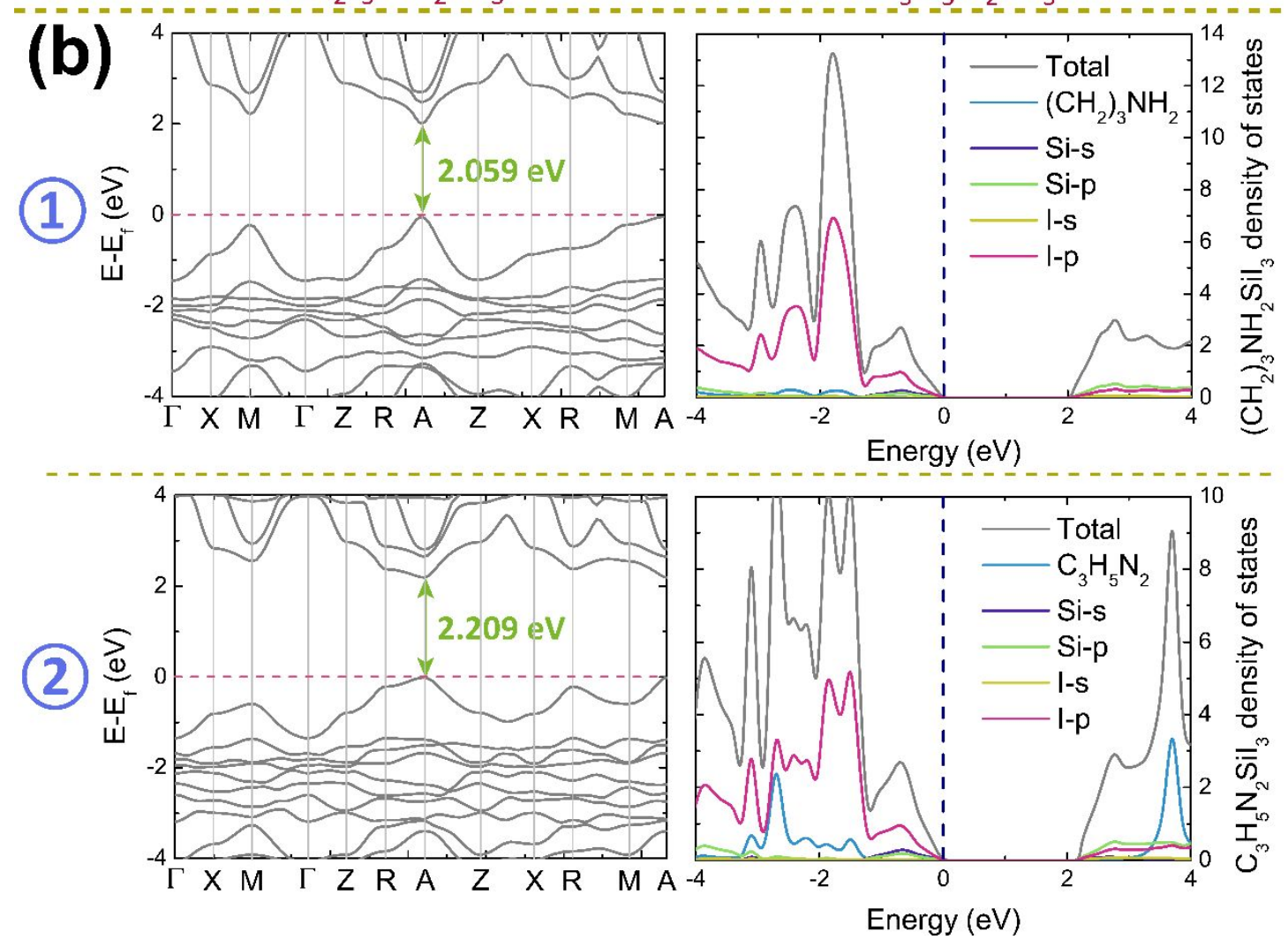

Figure S5. (a) The optimized structures, (b) band structures and PDOS for $\left(\mathrm{CH}_{2}\right)_{3} \mathrm{NH}_{2} \mathrm{SiI}_{3}$ and $\mathrm{C}_{3} \mathrm{H}_{5} \mathrm{~N}_{2} \mathrm{SiI}_{3}$. 


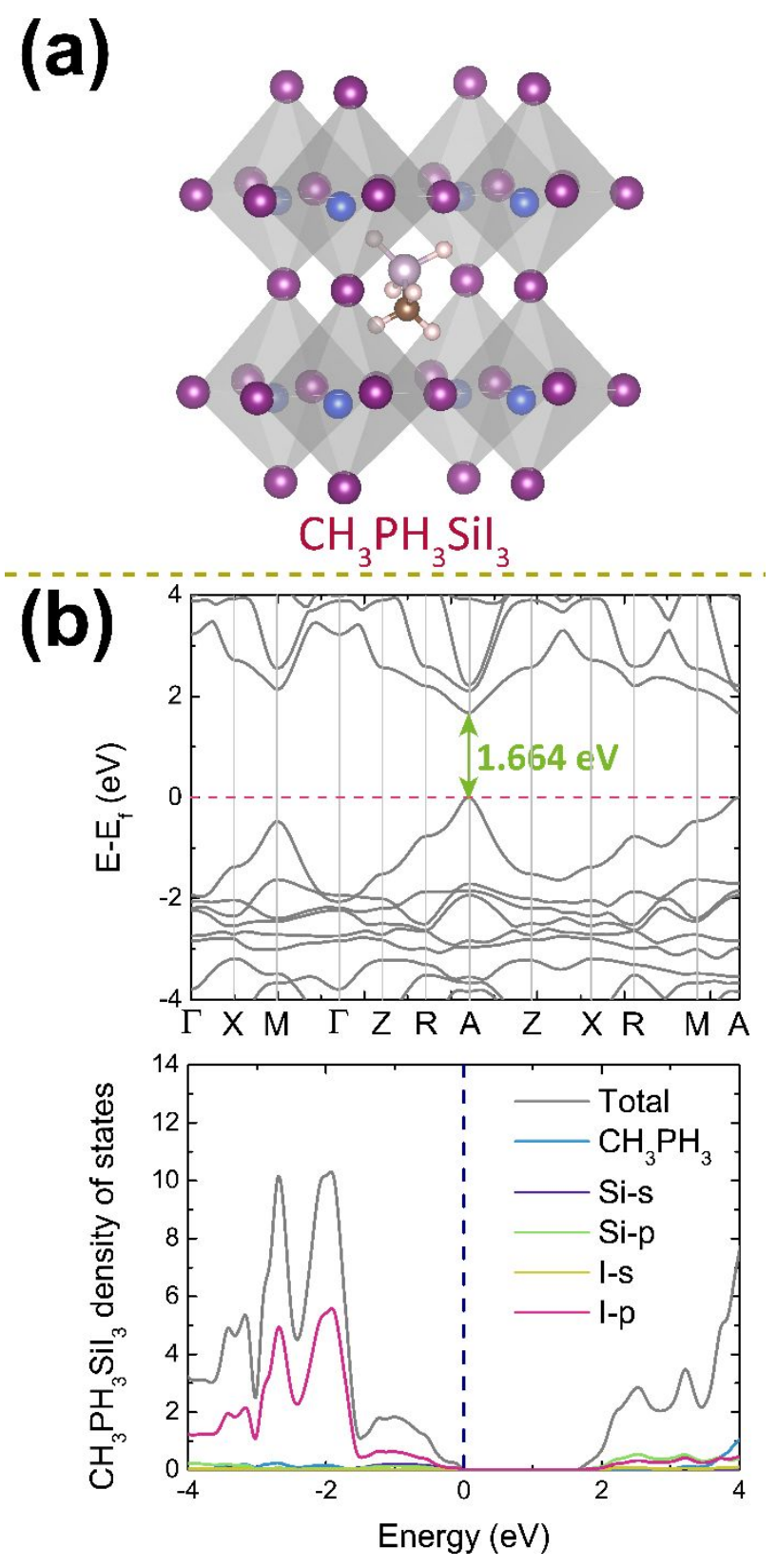

Figure S6. (a) The optimized structures, (b) band structures and PDOS for $\mathrm{CH}_{3} \mathrm{PH}_{3} \mathrm{SiI}_{3}$. 
Table S1. Lattice parameters of nine selected HOIPs

\begin{tabular}{|c|cccccc|}
\hline HOIPs & $\boldsymbol{a}(\AA)$ & $\boldsymbol{b}(\AA)$ & $\boldsymbol{c}(\AA)$ & $\boldsymbol{\alpha}\left(\mathbf{(}^{\mathbf{(}}\right)$ & $\boldsymbol{\beta}\left(^{\mathbf{(}}\right)$ & $\boldsymbol{\gamma}\left(^{\mathbf{o}}\right)$ \\
\hline $\mathrm{NH}_{4} \mathrm{SiBr}_{3}$ & 5.688 & 5.689 & 5.687 & 81.417 & 81.434 & 81.273 \\
$\mathrm{CH}_{3} \mathrm{NH}_{3} \mathrm{SiBr}_{3}$ & 5.798 & 5.671 & 5.824 & 90.663 & 98.504 & 89.232 \\
$\mathrm{SH}_{3} \mathrm{SiBr}_{3}$ & 5.553 & 5.581 & 5.701 & 89.801 & 87.637 & 87.478 \\
$\left(\mathrm{CH}_{3}\right)_{2} \mathrm{NH}_{2} \mathrm{SiI}_{3}$ & 6.349 & 6.482 & 6.398 & 81.816 & 79.573 & 79.314 \\
$\mathrm{CH}_{3} \mathrm{CH}_{2} \mathrm{NH}_{3} \mathrm{SiI}_{3}$ & 6.358 & 6.179 & 6.497 & 82.604 & 85.133 & 92.333 \\
$\mathrm{HC}_{\left(\mathrm{NH}_{2}\right)_{2} \mathrm{SiI}_{3}}^{6.116}$ & 6.293 & 6.231 & 80.630 & 86.641 & 85.392 \\
$\left(\mathrm{CH}_{2}\right)_{3} \mathrm{NH}_{2} \mathrm{SiI}_{3}$ & 6.254 & 6.278 & 6.607 & 94.337 & 88.478 & 89.016 \\
$\mathrm{C}_{3} \mathrm{H}_{5} \mathrm{~N}_{2} \mathrm{SiI}_{3}$ & 6.809 & 6.282 & 6.383 & 84.450 & 85.678 & 94.659 \\
$\mathrm{CH}_{3} \mathrm{PH}_{3} \mathrm{SiI}_{3}$ & 6.070 & 6.261 & 6.327 & 85.726 & 85.230 & 83.093 \\
\hline $\boldsymbol{a}, \boldsymbol{b}$, and $\boldsymbol{c}$ are lattice length of unit cell for each HOIPs. $\alpha, \beta$, and $\gamma$ represent the lattice angle. \\
\hline
\end{tabular}


Table S2. Computed effective masses of 13 selected HOIPs by using HSE06 hybrid functional. $\left(m_{e}\right)$

\begin{tabular}{|c|cc|}
\hline \multicolumn{1}{|c}{ HOIPs } & VBM & CBM \\
\hline $\mathrm{CH}_{3} \mathrm{NH}_{3} \mathrm{PbI}_{3}$ & 0.33 & 0.28 \\
$\mathrm{NH}_{4} \mathrm{SiBr}_{3}$ & 0.328 & 0.889 \\
$\mathrm{CH}_{3} \mathrm{NH}_{3} \mathrm{SiBr}_{3}$ & 0.323 & 0.843 \\
$\mathrm{OHNH}_{3} \mathrm{SiBr}_{3}$ & 0.274 & 0.968 \\
$\mathrm{NH}_{2} \mathrm{NH}_{3} \mathrm{SiBr}_{3}$ & 0.435 & 0.403 \\
$\mathrm{SH}_{3} \mathrm{SiBr}_{3}$ & 0.228 & 0.986 \\
$\mathrm{CH}_{3} \mathrm{NH}_{3} \mathrm{SiI}_{3}$ & 0.247 & 0.372 \\
$\left(\mathrm{CH}_{3}\right)_{2} \mathrm{NH}_{2} \mathrm{SiI}_{3}$ & 0.493 & 0.593 \\
$\mathrm{CH}_{3} \mathrm{CH}_{2} \mathrm{NH}_{3} \mathrm{SiI}_{3}$ & 0.347 & 0.323 \\
$\left.\mathrm{HC}_{2} \mathrm{NH}_{2}\right)_{2} \mathrm{SiI}_{3}$ & 0.256 & 0.305 \\
$\left(\mathrm{CH}_{2}\right)_{3} \mathrm{NH}_{2} \mathrm{SiI}_{3}$ & 0.284 & 0.235 \\
$\mathrm{C}_{3} \mathrm{H}_{5} \mathrm{~N}_{2} \mathrm{SiI}_{3}$ & 0.762 & 0.606 \\
$\mathrm{CH}_{3} \mathrm{SH}_{2} \mathrm{SiI}_{3}$ & 0.336 & 0.427 \\
$\mathrm{CH}_{3} \mathrm{PH}_{3} \mathrm{SiI}_{3}$ & 0.243 & 0.453 \\
\hline Previous calculated effective masses of $\mathrm{CH}_{3} \mathrm{NH}_{3} \mathrm{PbI}_{3}$ are also \\
introduced for comparison. & \\
\hline
\end{tabular}


(a)
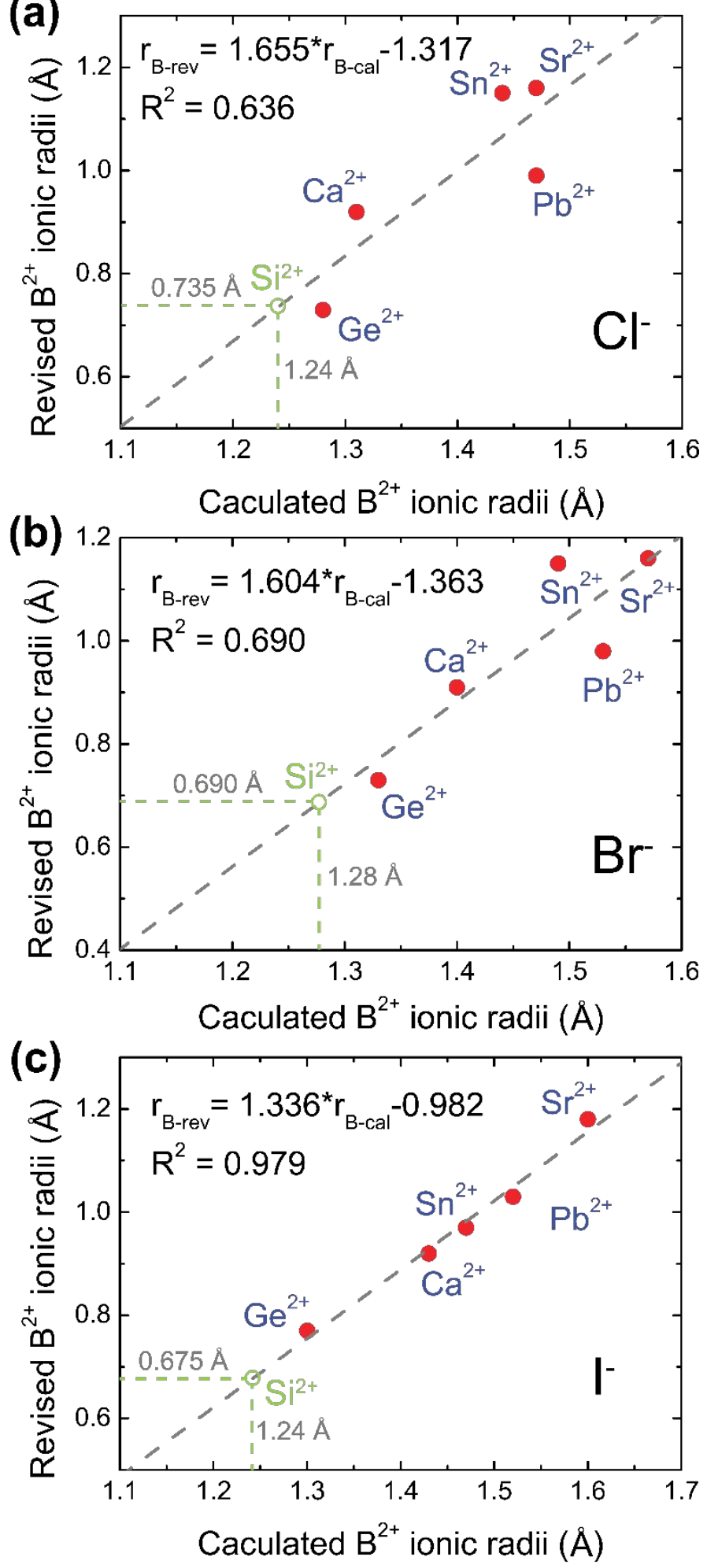

Figure S7. Linear fit between the calculated ionic radii and the revised ionic radii of $\mathrm{B}^{2+}$ cations (Ref. 1-2), as the $\mathrm{B}^{2+}$ cation filled in the (a) Chloride $\mathrm{X}_{6}$ octahedron, (b) Bromine $\mathrm{X}_{6}$ octahedron (c) Iodine $\mathrm{X}_{6}$ octahedron. The calculated and the linear fitted ionic radii of $\mathrm{Si}^{2+}$ are also shown in the graph. 
Table S3. Revised ionic radii of $\mathrm{B}^{2+}$ filled in the different halide $\mathrm{X}_{6}$ octahedron. (A)

\begin{tabular}{c|ccc}
$\mathbf{B}^{2+}$ cation & $\mathbf{C l}^{-}$ & $\mathbf{B r}^{-}$ & $\mathbf{I}^{-}$ \\
$\mathrm{Ge}^{2+}$ & 0.73 & 0.73 & 0.77 \\
$\mathrm{Ca}^{2+}$ & 0.92 & 0.91 & 0.92 \\
$\mathrm{Sn}^{2+}$ & 1.15 & 1.15 & 0.97 \\
$\mathrm{~Pb}^{2+}$ & 0.99 & 0.98 & 1.03 \\
$\mathrm{Sr}^{2+}$ & 1.16 & 1.16 & 1.18 \\
$\mathrm{Si}^{2+}$ & 0.735 & 0.690 & 0.675
\end{tabular}

Shannon ionic radii applied in current study are highlighted by light green color. ${ }^{1}$ The evaluated ionic radii of $\mathrm{Si}^{2+}$, obtained by linear fitting, are labeled by red color. And, the remaining part of revised ionic radii are achieved from Ref. 2-3. 


\section{Table S4. Nine selected HOIPs with relevant properties}

\begin{tabular}{|c|c|c|c|c|c|c|}
\hline HOIPs & $T_{f}$ & $\boldsymbol{O}_{f}$ & $\begin{array}{c}E_{g} P B E \\
(\mathrm{eV})\end{array}$ & $\begin{array}{c}E_{g} H S E 06 \\
(\mathrm{eV})\end{array}$ & $\begin{array}{c}E_{f} \\
\text { (eV/Atom) }\end{array}$ & $\begin{array}{c}\Delta E_{a b s-O 2} \\
(\mathrm{eV})\end{array}$ \\
\hline $\mathrm{NH}_{4} \mathrm{SiBr}_{3}$ & 0.913 & 0.352 & 1.452 & 2.274 & -0.868 & -0.969 \\
\hline $\mathrm{CH}_{3} \mathrm{NH}_{3} \mathrm{SiBr}_{3}$ & 1.003 & 0.352 & 1.321 & 2.242 & -0.681 & -0.231 \\
\hline $\mathrm{SH}_{3} \mathrm{SiBr}_{3}$ & 1.038 & 0.352 & 0.812 & 1.586 & -0.795 & -0.132 \\
\hline$\left(\mathrm{CH}_{3}\right)_{2} \mathrm{NH}_{2} \mathrm{SiI}_{3}$ & 1.210 & 0.307 & 1.391 & 2.145 & -0.438 & -0.239 \\
\hline $\mathrm{CH}_{3} \mathrm{CH}_{2} \mathrm{NH}_{3} \mathrm{SiI}_{3}$ & 1.215 & 0.307 & 1.168 & 1.880 & -0.438 & -0.558 \\
\hline $\mathrm{HC}\left(\mathrm{NH}_{2}\right)_{2} \mathrm{SiI}_{3}$ & 1.163 & 0.307 & 1.062 & 1.653 & -0.580 & -0.708 \\
\hline$\left(\mathrm{CH}_{2}\right)_{3} \mathrm{NH}_{2} \mathrm{SiI}_{3}$ & 1.156 & 0.307 & 1.312 & 2.059 & -0.419 & -0.031 \\
\hline $\mathrm{C}_{3} \mathrm{H}_{5} \mathrm{~N}_{2} \mathrm{SiI}_{3}$ & 1.176 & 0.307 & 1.458 & 2.209 & -0.469 & -0.402 \\
\hline $\mathrm{CH}_{3} \mathrm{PH}_{3} \mathrm{SiI}_{3}$ & 1.154 & 0.307 & 1.021 & 1.664 & -0.481 & -0.149 \\
\hline \multicolumn{7}{|c|}{$\begin{array}{l}T_{f} \text { and } O_{f} \text { represent the tolerance factor and octahedral factor of Si-based HOIPs. } E_{g}{ }^{P B E}, E_{g}{ }^{H S E 06} \\
\text { and } E_{f} \text { is DFT-calculated bandgap value achieved by PBE and HSE06 functional, and formation } \\
\text { energy, respectively. } \Delta \mathrm{E}_{\text {abs-H2O }} \text { is the absorption energy of } \mathrm{H}_{2} \mathrm{O} \text { on the surface of Silicon-based } \\
\text { HOIPs. }\end{array}$} \\
\hline
\end{tabular}


(a)
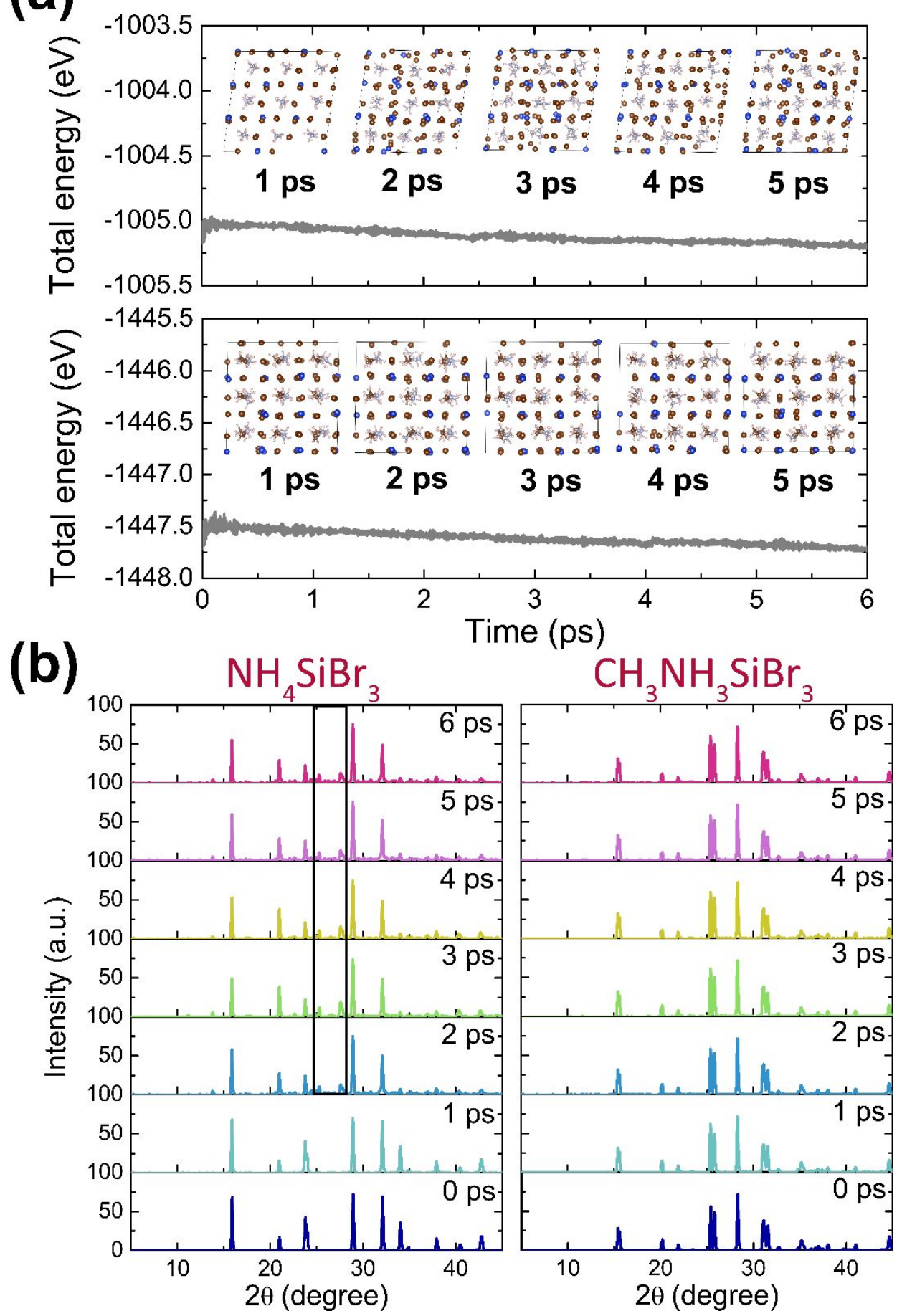

Figure S8. (a) Total energy during 6 ps AIMD simulations for (Upper) $\mathrm{NH}_{4} \mathrm{SiBr}_{3}$ and (Lower) $\mathrm{CH}_{3} \mathrm{NH}_{3} \mathrm{SiBr}_{3}$, and (b) corresponding simulated XRD pattern at room temperature. 
(a)
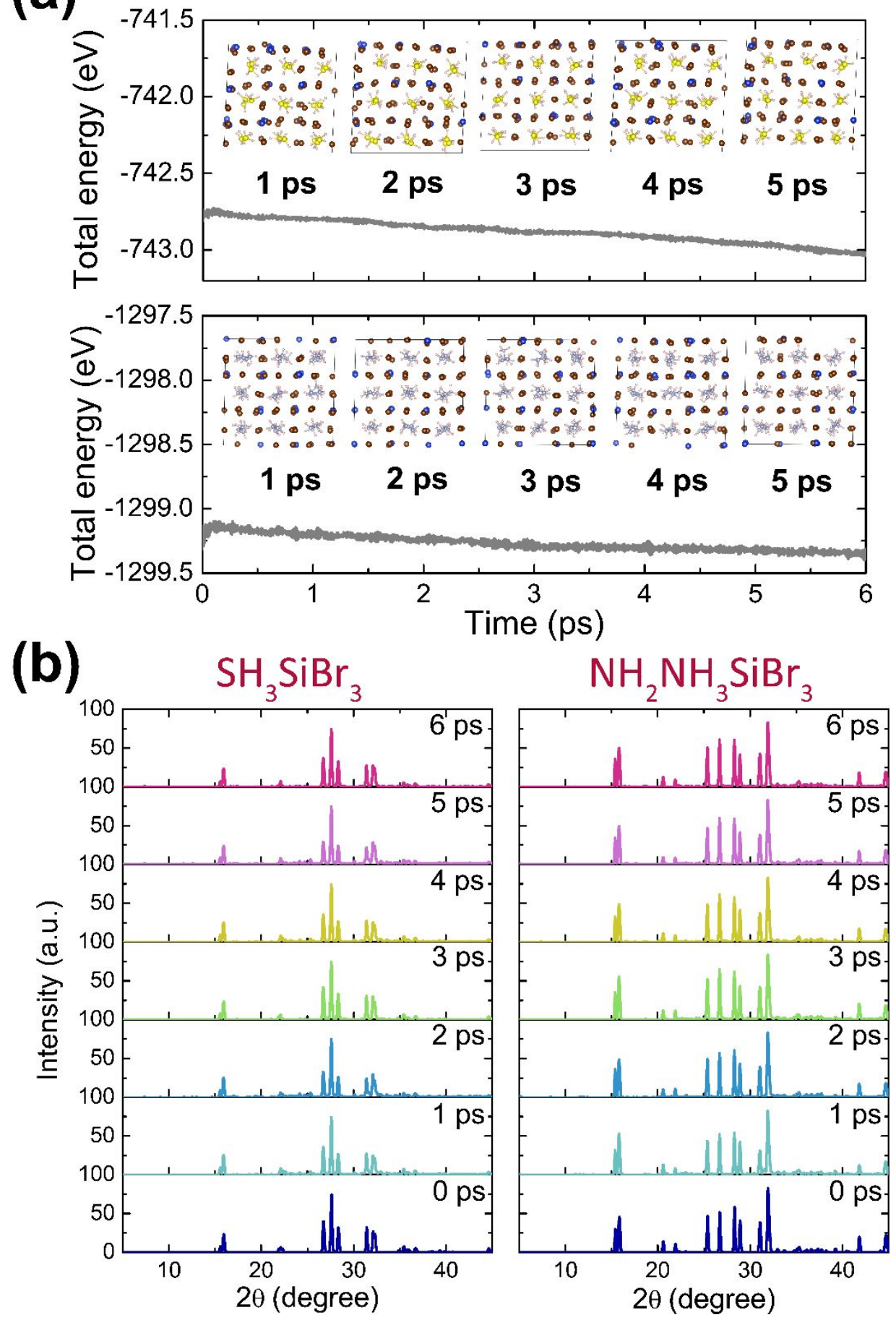

Figure S9. (a) Total energy during 6 ps AIMD simulations for (Upper) $\mathrm{SH}_{3} \mathrm{SiBr}_{3}$ and (Lower) $\mathrm{NH}_{2} \mathrm{NH}_{3} \mathrm{SiBr}_{3}$, and (b) corresponding simulated XRD pattern at room temperature. 
(a)
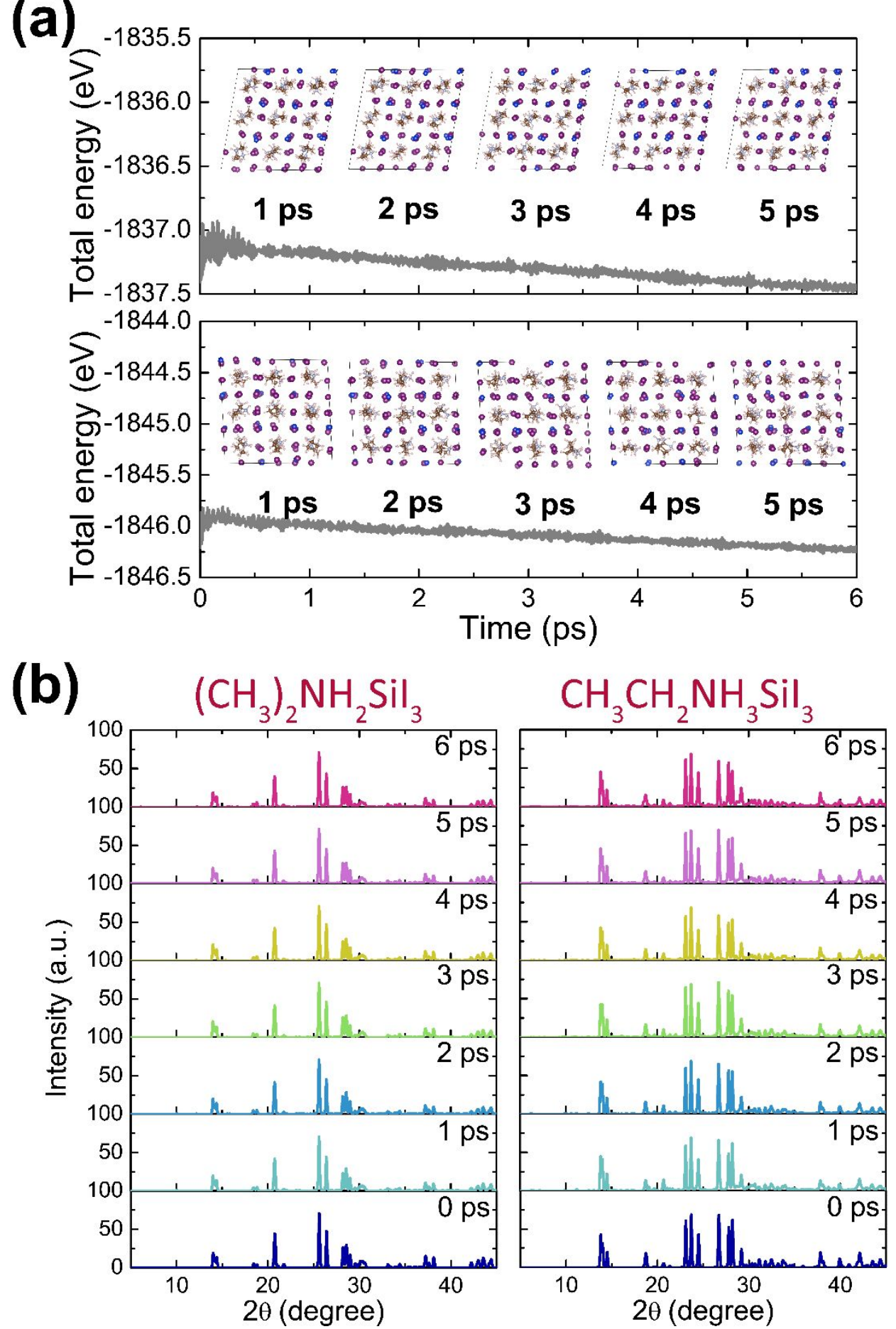

Figure S10. (a) Total energy during 6 ps AIMD simulations for (Upper) $\left(\mathrm{CH}_{3}\right)_{2} \mathrm{NH}_{2} \mathrm{SiI}_{3}$ and (Lower) $\mathrm{CH}_{3} \mathrm{CH}_{2} \mathrm{NH}_{3} \mathrm{SiI}_{3}$, and (b) corresponding simulated XRD pattern at room temperature. 

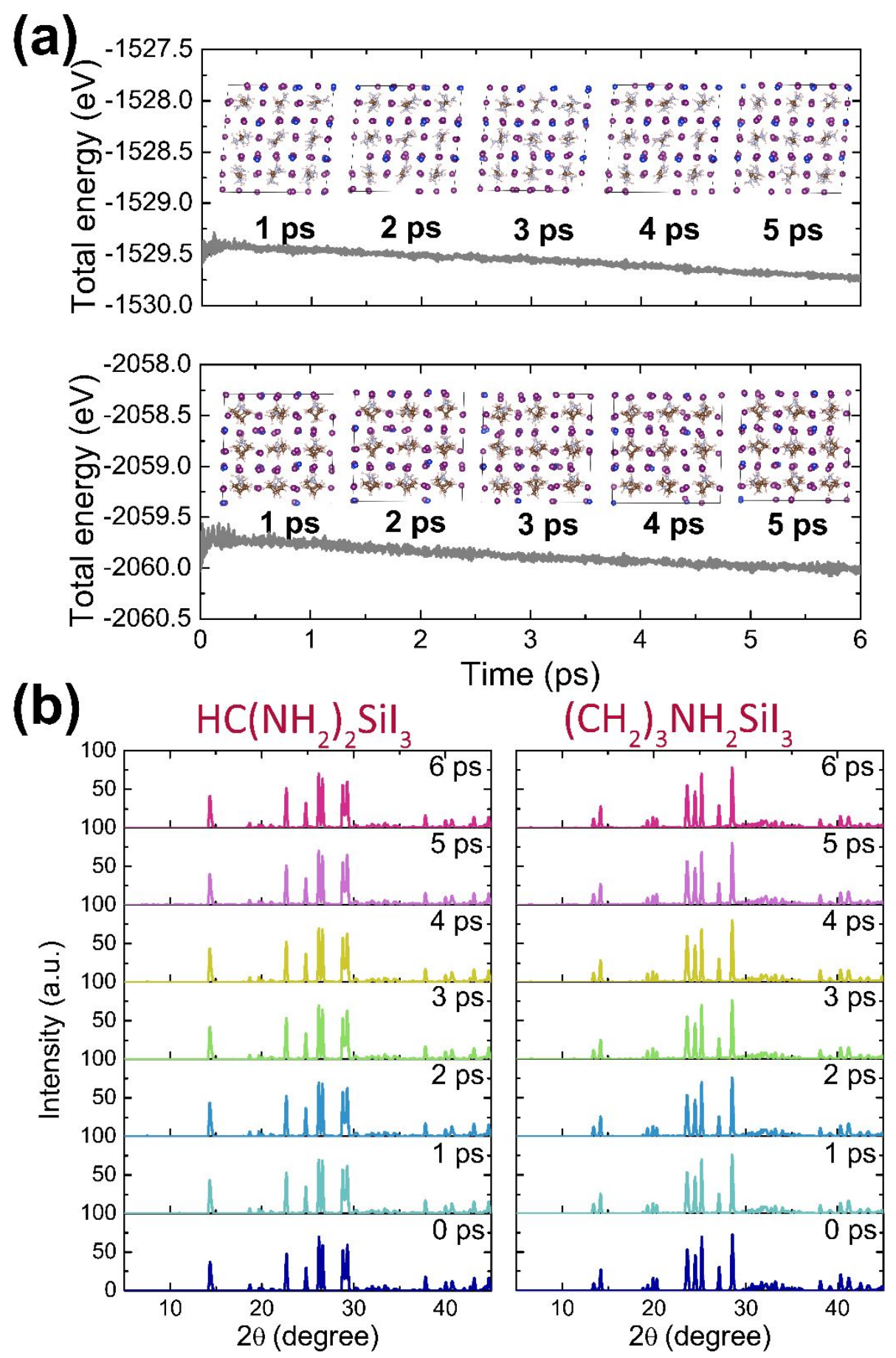

Figure S11. (a) Total energy during 6 ps AIMD simulations for (Upper) $\mathrm{HC}\left(\mathrm{NH}_{2}\right)_{2} \mathrm{SiI}_{3}$ and (Lower) $\left(\mathrm{CH}_{2}\right)_{3} \mathrm{NH}_{2} \mathrm{SiI}_{3}$, and (b) corresponding simulated XRD pattern at room temperature. 
(a)
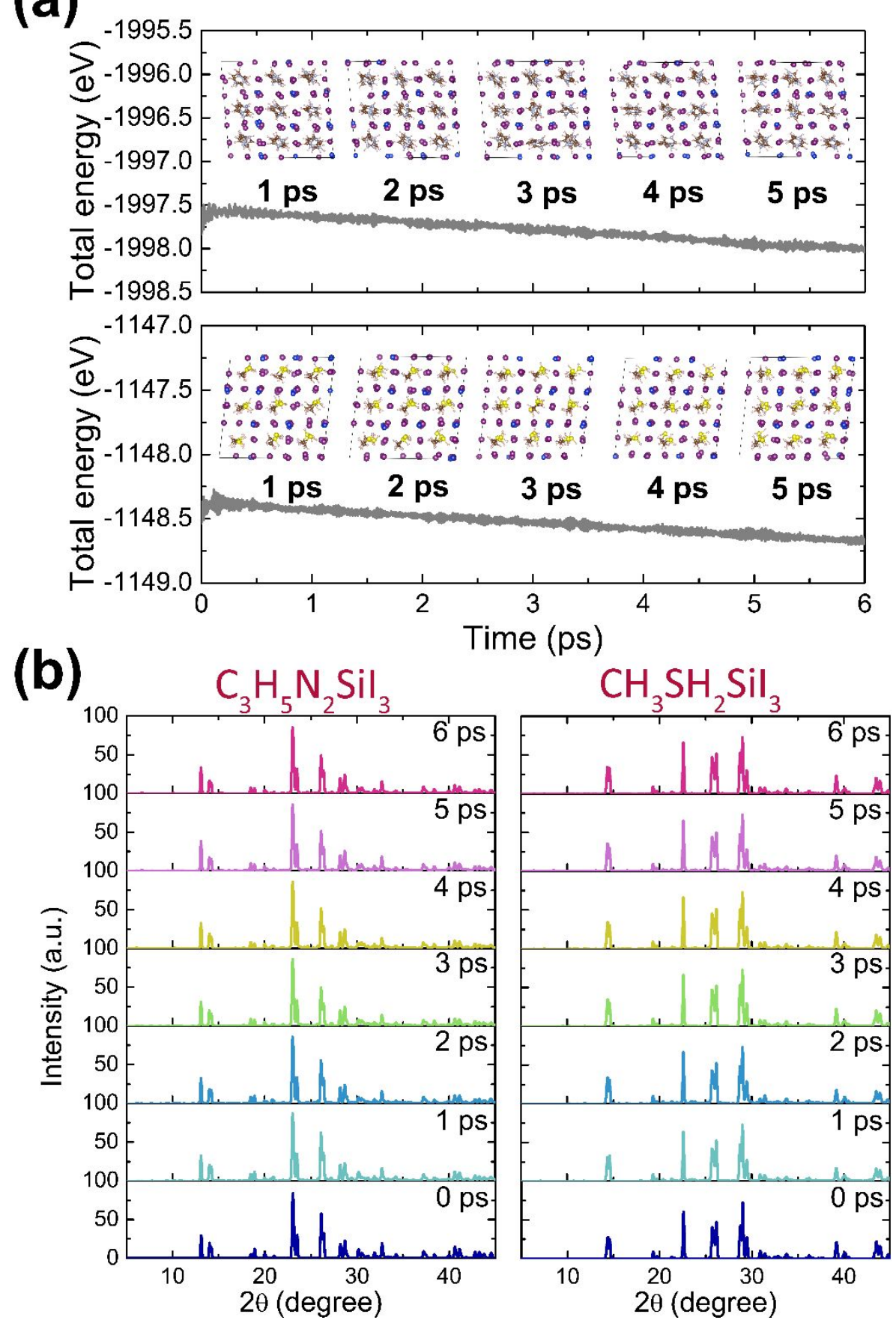

Figure S12. (a) Total energy during 6 ps AIMD simulations for (Upper) $\mathrm{C}_{3} \mathrm{H}_{5} \mathrm{~N}_{2} \mathrm{SiI}_{3}$ and (Lower) $\mathrm{CH}_{3} \mathrm{SH}_{2} \mathrm{SiI}_{3}$, and (b) corresponding simulated XRD pattern at room temperature. 
(a)

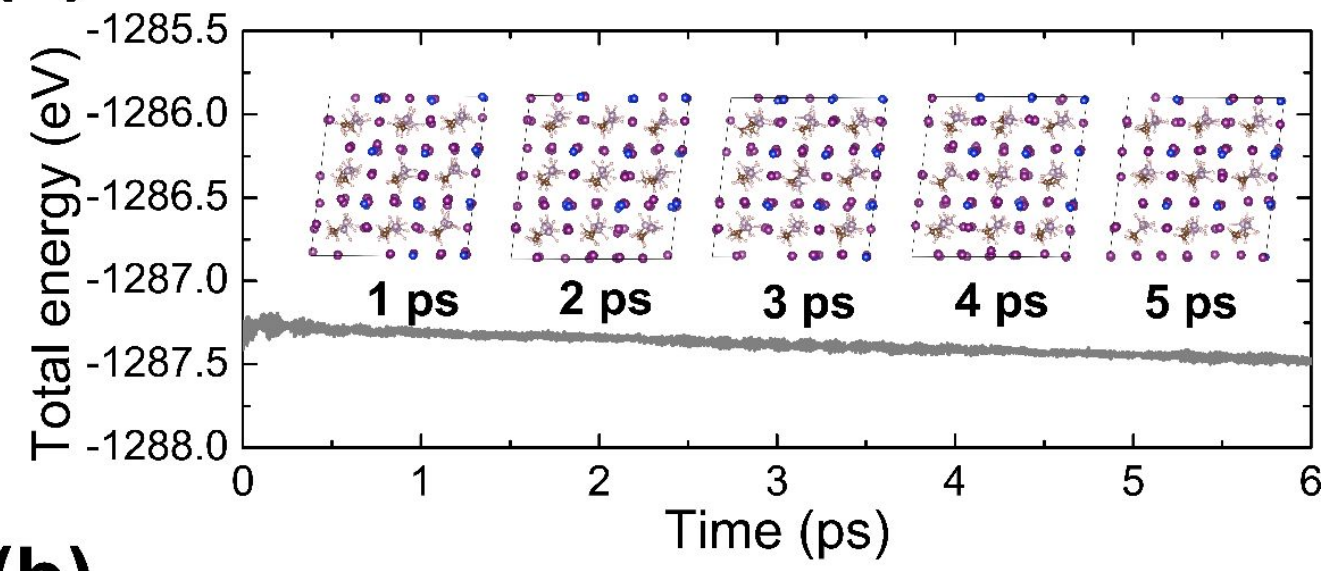

(b)

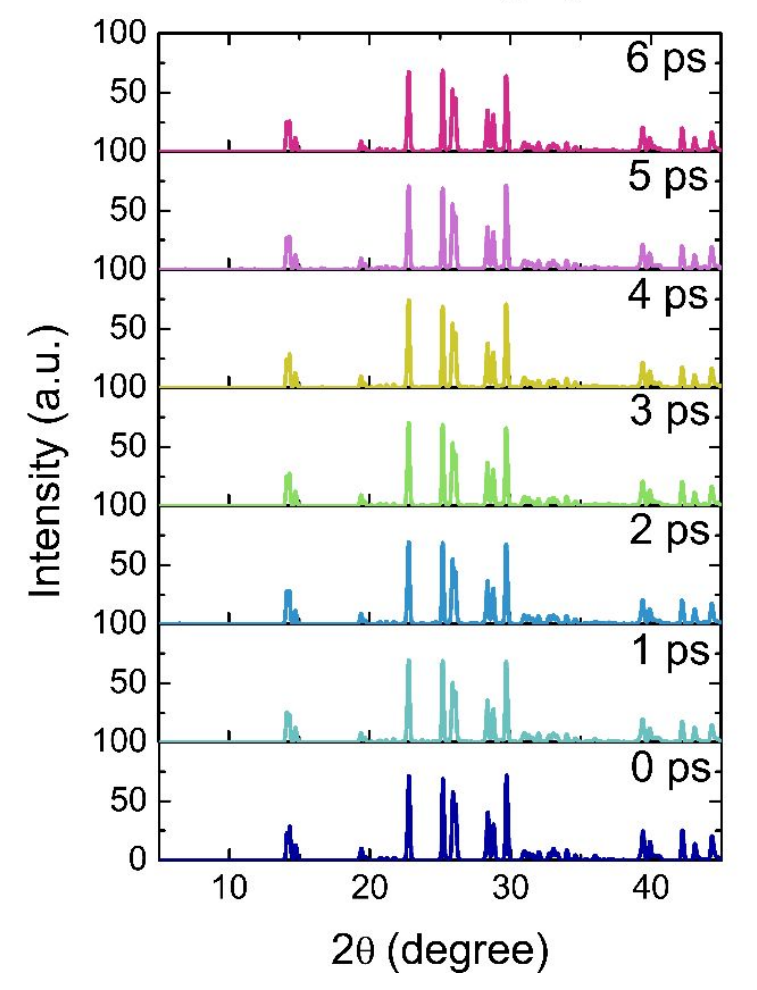

Figure S13. (a) Total energy during 6 ps AIMD simulations for $\mathrm{CH}_{3} \mathrm{PH}_{2} \mathrm{SiI}_{3}$, and (b) corresponding simulated XRD pattern at room temperature. 


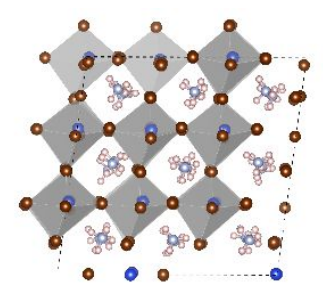

1 ps
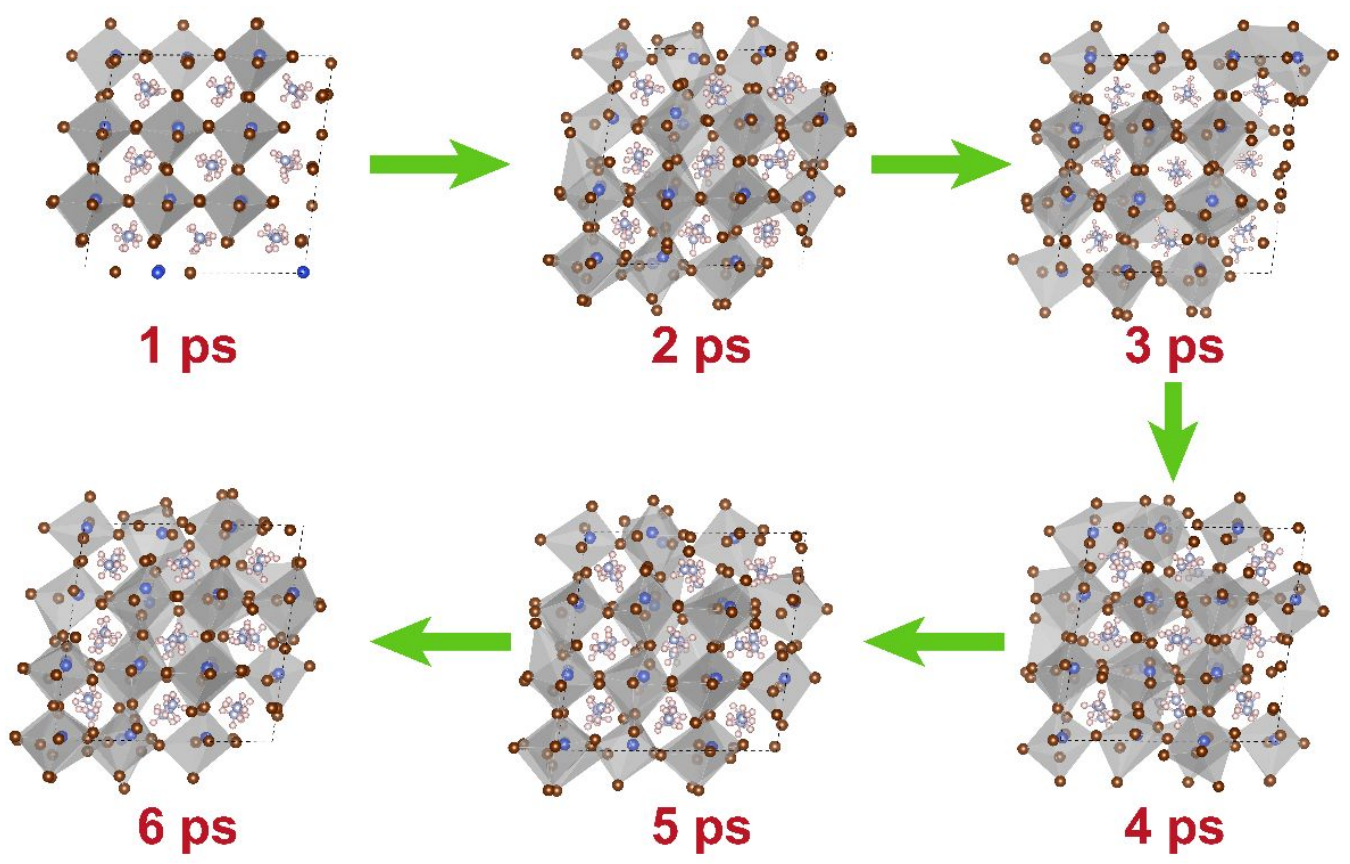

Figure S14. Snapshots of $\mathrm{NH}_{4} \mathrm{SiBr}_{3}$, taken at the first and every pico-second of 6 ps AIMD simulation trajectory. 


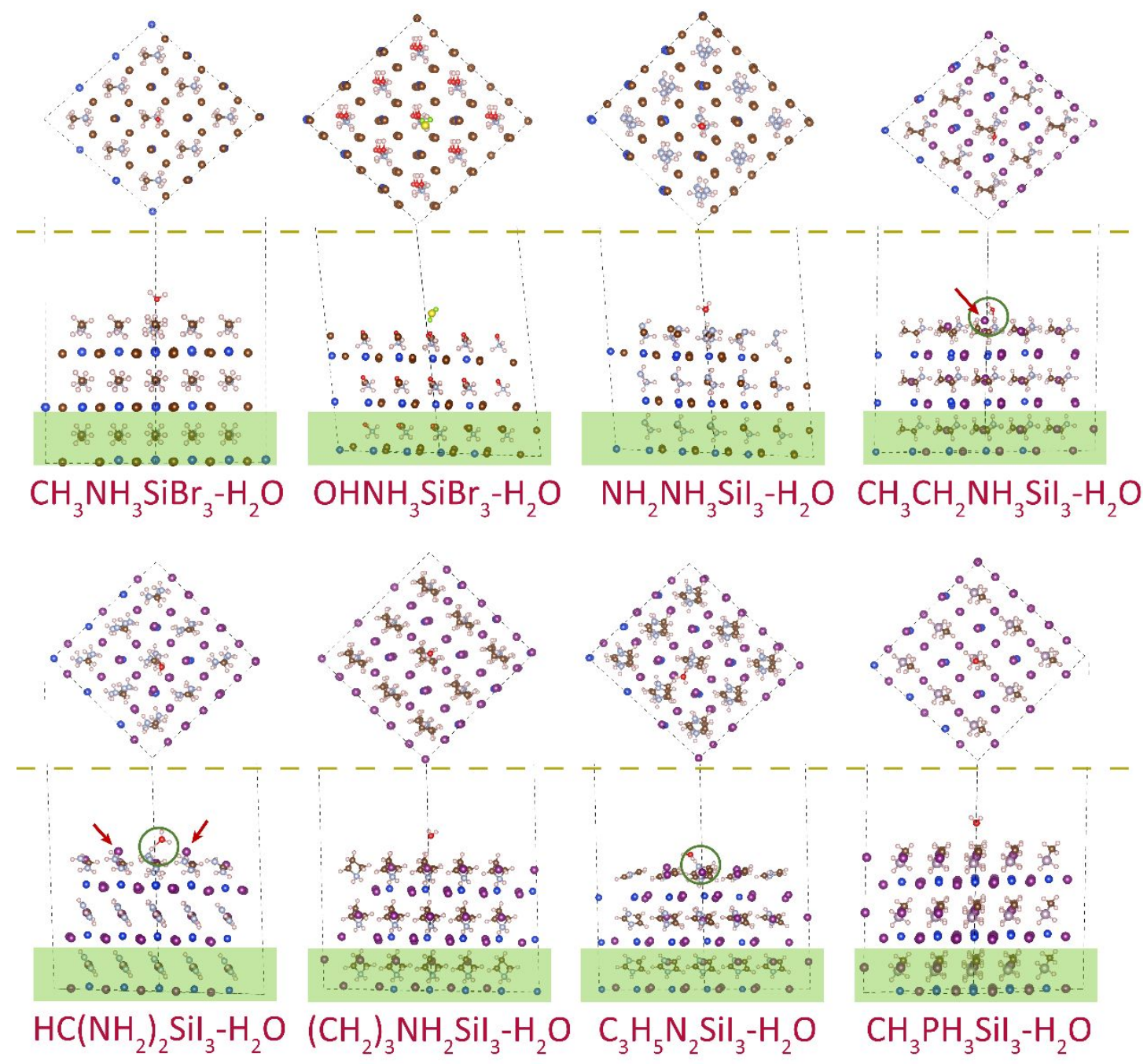

Figure S15. Structure of HOIPs with one $\mathrm{H}_{2} \mathrm{O}$ adsorbed on surface after optimization. Top and Side view of $\mathrm{H}_{2} \mathrm{O}$ molecular absorbed on the surface of 8 Silicon-based HOIPs, where atoms are fixed in the green region for DFT calculation. The red arrow and green cycle represent the obvious distortions of perovskite framework at the surface and hydrogen-bonding with water at the surface, respectively. 


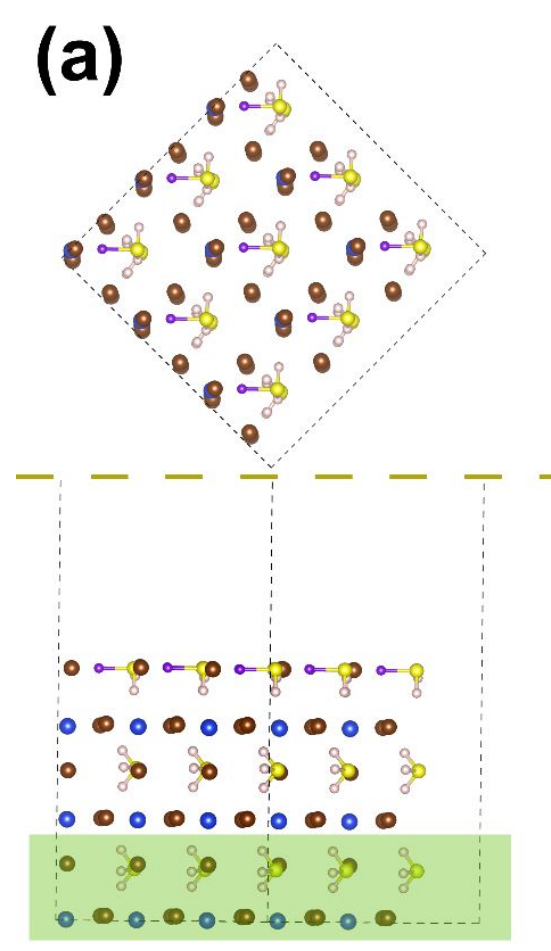

$\mathrm{SH}_{3} \mathrm{SiBr}_{3}$ (b)
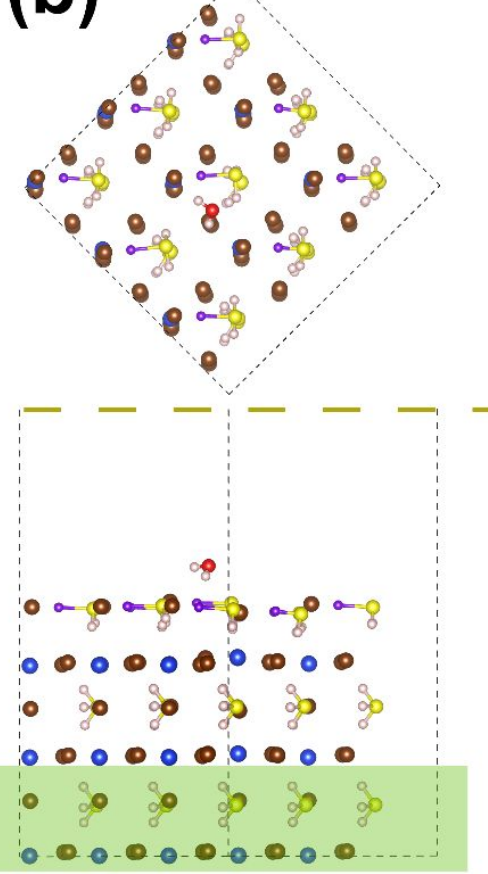

$\mathrm{SH}_{3} \mathrm{SiBr}_{3}-\mathrm{H}_{2} \mathrm{O}$

Figure S16. (a) Structure of $\mathrm{SH}_{3} \mathrm{SiBr}_{3}$ at the vacuum surface and (b) with one $\mathrm{H}_{2} \mathrm{O}$ adsorbed on surface after optimization. Top and Side view of optimized structure, where atoms are fixed in the green region for DFT calculation. The outmost hydrogen atom is highlighted by purple color. 


\section{References}

(1) Shannon, R. D., Revised effective ionic radii and systematic studies of interatomic distances in halides and chalcogenides. Acta Crystallographica 1976, 32, 751-767.

(2) Becker, M.; Kluner, T.; Wark, M., Formation of hybrid $\mathrm{ABX}_{3}$ perovskite compounds for solar cell application: first-principles calculations of effective ionic radii and determination of tolerance factors. Dalton Trans 2017, 46, 3500-3509.

(3) Travis, W.; Glover, E. N. K.; Bronstein, H.; Scanlon, D. O.; Palgrave, R. G., On the application of the tolerance factor to inorganic and hybrid halide perovskites: a revised system. Chem. Sci. 2016, 7, $4548-4556$. 